\title{
PENGARUH KINERJA PEGAWAI TERHADAP EFEKTIVITAS ORGANISASI PADA KANTOR KECAMATAN DUSUN SELATAN KABUPATEN BARITO SELATAN
}

\author{
The Effect of Employee Performance on Organizational Effectiveness in the Kecamatan Dusun \\ Selatan Office of Selatan Barito District
}

\section{Emil S Nugraha}

STIE Dahani Dahanai, Buntok, Kalimantan Tengah, Indonesia.

Email:

salim.emil23@gmail.com

Keywords :

Performance

Organizational

Effectiveness

Kata Kunci :

Kinerja

Efektivitas

Organisasi

\section{Abstrak}

Penelitian ini bertujuan untuk untuk mengetahuai Pengaruh Kinerja Pegawai Terhadap Efektivitas Organisasi pada Kantor Kecamatan Dusun Selatan Kabupaten Barito Selatan Tahun 2020.

Teori yang digunakan dalam penelitian ini yaitu Kinerja pada organisasi dapat dilihat dari Produktivitas, Kualitas Layanan, Responsivitas, Responsibilitas, Akuntabilitas pegawai itu sendiri menurut Agus Dwiyanto (2008:50-5I) dan Efektivitas yang berasal dari kata efektif, yaitu suatu pekerjaan dikatakan efektif jika suatu pekerjaan dapat menghasilkan satu unit keluaran (output). Suatu pekerjaan dikatakan efektif jika suatu pekerjaan dapat diselesaikan tepat pada waktunya sesuai dengan rencana yang telah ditetapkan, terdapat indikator yang mempengaruhi efektivitas organisasi ada beberapa bagian yaitu pencapaian tujuan, integrasi, adaptasi. Menurut Duncan dikutip oleh Richard M. Steers (1985:9) dalam Zulkarnain (2012:42)

Penelitian ini menggunakan metode kuantitatif dengan teknik pengumpulan data menggunakan observasi, wawancara, dukomentasi dan kuisioner. Penelitian ini mempunyaib dua variabel yaitu variabel indevenden $(X)$ Kinerja Pegawai devenden $(Y)$ Efektivitas Organisasi. Alat analisis yang digunakan yaitu Regresi Sederhana dengan menggunakan SPSS Versi 25.

Hasil yang diperoleh dalam perhitungan regresi sederhana adalah $Y=7,098+$ $0,848 \times$ diman nilai (a) sebesar 7,098 dan nilai kofisien (b) adalah 0,848. Kemudian diperoleh hasil $t_{\text {hitung }}$ dari pengujian di atas bahwa $t_{\text {hitung }}>t_{\text {abel }}(6,538>2,042)$ maka Ho ditolak dan Ha diterima. Artinya bahwa ada pengaruh secara signifikan antara Kinerja Pegawai Terhadapa Efektivitas Organisasi pada kntor Kecamatan Dusun Selatan Kabupaten Barito Selatan Tahun 2020.

\section{Abstract}

This study aims to determine the Effect of Employee Performance on Organizational Effectiveness at the Dusun Selatan District Office, South Barito Regency in 2020.

The theory used in this research is the performance in the organization which can be seen from the productivity, service quality, responsiveness, responsibility, employee accountability according to Agus Dwiyanto (2008: 50-5I) and effectiveness which comes from the word effective, which is a job that is said to be effective if a job can produce one unit of output (output). A job is said to be effective if a job can be completed on time according to a predetermined plan, there are indicators that affect organizational effectiveness, there are several parts, namely goal achievement, integration, adaptation. According to Duncan quoted by Richard M. Steers (1985: 9) in Zulkarnain (2012: 42)

This research uses quantitative methods with data collection techniques using observation, interviews, documentation and questionnaires. This research has two variables, namely independent variable (X) Devendent employee performance (Y) Organizational Effectiveness. The analytical tool used is simple regression using SPSS Version 25.

The results obtained in the simple regression calculation are $Y=7.098+0.848 X$ where the value (a) is 7.098 and the coefficient value $(b)$ is 0.848 . Then the results of tcount from the above test show that tcount> table $(6,538>2,042)$ then $\mathrm{Ho}$ is rejected and $\mathrm{Ha}$ is accepted. This means that there is a significant influence between Employee Performance on Organizational Effectiveness at Dusun Selatan District Heads in South Barito Regency in 2020.
Published

October 2020 


\section{PENDAHULUAN}

Pada umumnya dalam suatu instansi atau organisasi, baik itu Intansi Pemerintahan maupun sawasta sangat diperlukan peranan yang berupa kinerja dari pegawai, karena pegawai sangat menentukan tercapainya atau tidaknya suatu tujuan dari organisasi atau Instansi Pemerintahan tersebut sesuai dengan peranan dari pegawai tersebut, maka dalam UndangUndang Republik Indonesia Nomor 43 Tahun 1999 tentang perubahan atas Undang-Undangn Nomor 8 Tahun 1947 tentang pokok-pokok kepegawaian yang tertuang dalam Pasal I Ayat I.

Disebut bahwa Pegawai Negeri adalah Setiap Warga Negara Republik Indonesia yang telah memenuhi syarat yang ditentukan, diangkat oleh pejabat yang berwenang dan disertai tugas dalam suatu jabatan negeri, atau diserahi tugas Negara lainnya, dan gaji berdasarkan peraturan perundang-undangan yang berlaku.

Peraturan Pemerintah Nomor 53 Tahun 2010 mengenai kewajiban dari Pegawai Negeri dapat mencerminkan kesigapan pegawai dalam bekerja dan kedisiplinan pegawai dalam menaati peraturan kantor, itu merupaakan bentuk peranan Pegawai Negeri sangatlah penting peranannya dalam menjaga kelancaran jalanya suatu roda organisasi serta sangat menentukan dalam pencapaian tujuan yang lebih telah ditetapkan.

Setelah disahkannya Undang-Undang Nomor 23 Tahun 2014 tentang pemerintahan daerah, maka dimulailah babak baru bagi pemerintahan daerah di Indonesia dengan diterapkannya otonomi daerah. Di Indonesia otonomi daerah atau desentralisasi dianggap sebagai salah satu agenda reformasi, dimana pemerintah daerah memiliki kewenangan untuk mengatur dan mengurus daerahnya sendiri sesuai dengan ketentuan perundang-undangan yang berlaku.

Pemerintah daerah baik provinsi maupun kabupaten/kota memiliki perangkat daerah tersendiri untuk menjalankan roda pemerintahannya. Salah satu perangkat daerah di Kabupaten/Kota adalah Kecamatan.
Kecamatan sebagai salah satu perangkat daerah yang memiliki kewenangan untuk mengurus hal-hal yang berkaitan dengan pemenuhan layanan yang dibutuhkan oleh masyarakat setempat.

Pembentukan kecamatan dimaksudkan untuk mempermudah jangkauan masyarakat dalam mengakses pelayanan sesuai dengan kebutuhan masing-masing sehingga tidak harus ke kantor Kabupaten/Kota. Provinsi dan Kabupaten/Kota memiliki kewenangan yang lebih besar dalam mengelola keuangan daerah dan sumber daya yang ada di daerahnya.

Undang-Undang Nomor 23 Tahun 2014 tentang Pemerintah Daerah pada prinsipnya mengubah system penyelenggaraan pemerintah daerah, sehingga daerah diarahkan untuk mempercepat terwujudnya kesejahteraan masyarakat dengan meningkatkan pelayanan, pemberdayaan dan peran masyarakat.

Kecamatan merupakan ujung tombak dari penyelenggaraan pemerintahan yang langsung berhadapan dengan masyarakat luas. Citra birokrasi pemerintahan secara keseluruhan akan banyak ditentukan oleh kinerja organisasi tersebut. Kecamatan juga merupakan pemberi pelayanan terdepan dari pemerintah pusat yang berhadapan langsung dengan masyarakat dan mempunyai tugas membina desa sehingga harus pula diselenggarakan secara berdayaguna dan berhasil guna.

Pembenahan dalam penyelenggaraan pemerintah yang berorientasi pada fungsi pelayanan masyarakat, hendaknya dititik beratkan pada Pemerintah Kecamatan. Karena kecamatan merupakan pusat pelaksanaan pelayanan kepada masyarakat.

Perbaikan dalam penyelenggaraan pemerintahan kecamatan harus dilakukan, terutama bagaimana menumbuhkan dan meningkatkan kinerja aparatur kantor Kecamatan sebagai abdi negara dan abdi masyarakat yang mau tidak mau harus berupaya meningkatkan kemampuan kerjanya semaksimal mungkin, karena pelaksanaan tugas pelayanan oleh pemerintah kecamatan sangat tergantung pada kinerja 
aparatnya. Sedangkan masyarakat hanya dapat menilai kinerja kantor kecamatan dari kualitas pelayanan yang diterimanya.

Keberhasilan pencapaian tujuan dalam suatu organisasi tidak terlepas dari kualitas Sumber Daya Manusia yang dimiliki kualitas yang baik akan diperoleh jika organisasi secara sungguh-sungguh memperhatikan serta mengetahui kebutuhan organisasi dan kemampuan karyawannya. Untuk mencapai tujuannya, suatu organisasi harus memiliki individu-individu dengan kualitas yang sesuai, jelas, tugas, wewenang, tanggung jawab hubungan dan tata kerjanya.

Ini dapat diwujudkan melalui aktivitas-aktivitas menajemen sumber daya manusia yang secara ringkas dapat juga dikatakan sebagai upaya pendayagunaan sumber daya manusia.

Kinerja pada dasarnya merupakan hasil kerja secara kualitas dan kuantitas yang dicapai seorang pegawai dalam melaksanakan tugasnya sesuai tanggung jawab yang diberikan kepadanya. Dalam hal ini, pegawai bisa belajar seberapa besar kinerja mereka melalui sarana informasi seperti komentar baik dari mitra kerja.

Namun demikian penilaian kinerja yang mengacu kepada suatu sistem formal dan terstruktur yang mengukur, menilai dan mempengaruhi sifat-sifat yang berkaitan dengan pekerjaan perilaku dan hasil termasuk tingkat ketidak hadiran.

Kinerja dalam organisasi merupakan jawaban dari berhasil atau tidaknya tujuan organisasi yang telah ditetapkan. Para pegawai sering tidak memperhatikan kecuali sudah amat buruk atau segala sesuatu jadi serba salah.

Efektivitas merupakan pencapaian suatu kegiatan sesuai dengan rencana. Suatu pekerjaan yang dilakukan oleh seseorang, akan menunjang pencapaian tujuan secara kelompok. Hal ini dikarenakan setiap organisasi terbagi menjadi beberapa bagian atau kelompok. Sementara itu, pencapaian tujuan kelompok akan mendukung pencapaian tujuan organisasi secara keseluruhan.
Keberhasilan kemimpinan dan organisasi diukur dengan konsep efektivitas itu sendiri, terdapat hubungan komunikasi yang kurang baik antara pegawai dengan pemimpin maupun sebaliknya, dalam menyelesaikan pekerjaan dan pegawai yang tidak bekerjasama dengan satu tim yang mereka naungi dalam satu seksi, kurang nya pelayanan yang baik yang di berikan oleh pegawai kepada masyarakat, dapat merugikan suaatu organisasi atau instansi yang dijalani, yaitu penilaian masyarakat terhadap organisasi /instansi tersebut.

Kualitas dan pencapaian kerja menjadi tidak Efektif dan Efisien dikarenaka kinerja pegawai menunjukan hasil kerja yang optimal terhadap kemajuan tujuan pencapaian organisasi, pada kantor Kecamatan Dusun Selatan terdapat uraian tugas pada masingmasing bidang pekerjaan yang telah ditetapkan oleh pemerintah daerah setempat, kinerja pegawai Kecamatan Dusun Selatan sudah melaksanakan uraian tugas tersebut, tetapi belum diketahui apakah sudah efektif dan efesien atau belum.

\section{LANDASAN TEORI}

\section{Kinerja}

Menurut Agus Dwiyanto (2017 : 47) konsep kinerja adalah Penilaian Kinerja merupakan suatu kegiatan yang sangat penting karena dapat digunakan sebagai ukuran keberhasilan suatu organisasi dalam mencapai misinya. Untuk organisasi pelayanan publik, informasi mengenai kinerja tentu sangat berguna untuk menilai seberapa jauh pelayanan yang diberikan oleh organisasi itu untuk memenuhi harapan dan memuaskan penggunaan jasa. Dengan melakukan penilaian terhadap kinerja, maka upaya untuk memperbaiki kinerja bisa dilakukan secara lebih terarah dan sistematis."

Menurut Agus Dwiyanto (2008) kinerja dalam organisasi merupakan jawaban dari berhasil atau tidaknya tujuan organisasi yang telah ditetapkan. Para pegawai sering tidak memperhatikan kecuali sudah amat buruk atau segala sesuatu jadi serba salah. Terlalu sering pegawai tidak mengetahui betapa buruknya kinerja telah 
merosot sehinnga organisasi dalam suatu intansi pemerintahan menghadapi krisis yang serius.

Kinerja dari Agus Dwiyanto (2017:50-5I) dalam buku Reformasi Birokrasi Publik di Indonesia terdapat indikator kinerja, yaitu:

I. Produktivitas

Menurut Dwiyanto (2017:50) Konsep produktivitas tidak hanya mengukur tingkat efesiensi, tetapi juga aktivitas pelayanan. Produktivitas pada umumnya dipahami sebagai rasio antara output dengan Input. Konsep produktivitas dirasa terlalu sempit dan kemudian General Accounting Offece (GAO) mencoba mengembangkan ukuran produktifitas yang lebih luas dengan memasukkan seberapa besar pelayanan publik itu memiliki hasil yang yang diharapkan sebagai salah satu indikator kinerja yang penting.

2. Kualitas Layanan

Isu mengenai kualitas layanan cenderung semakin menjadi penting dalam menjelaskan kinerja organisasi pelayanan publik. Banyak pandangan negatif yang terbentuk mengenai organisasi publik muncul karena ketidak puasan masyarakat terhadap kualitas layanan yang diterima dari organisasi publik.

Keuntungan utama menggunakan kepuasan masyarakat sebagai indikator kinerja adalah informasi mengenai kepuasan masyarakat sering kali tersedia secara mudah dan murah. Informasi mengenai kepuasan terhadap kualitas pelayanan seringkali dapat diperoleh dari media masa atau diskusi publik. Kualitas layanan adalah sesuatu yang sangat penting dalam mengukur kinerja organisasi publik. Menurut Dwiyanto (2017 :50). Banyak pandangan negatif yang terbentuk mengenai organisasi publik karena ketidak puasan masyarakat terhadap kualitas layanan yang diterima dari organisasi publik.

Dengan demikian, kepuasan masyarakat terhadap layanan dapat dijadikan indikator kinerja oganisasi publik. Keuntungan utama menggunakan kepuasan masyarakat sebagai indikator kinerja adalah Informasi mengenai kepuasan terhadap kualitas pelayanan sering kali dapat diperoleh dari media masa atau diskusi publik. Akibat akses terhadap informasi mengenai kepuasan masyarakat tehadap kualitas layanan relatif sangat tinggi, maka bisa menjadi satu ukuran kinerja organisasi publik yang mudah dan murah dipergunakan. Kepuasan masyarakat bisa dijadikan parameter untuk menilai kinerja organisasi publik.

3. Responsivitas

Responsivitas adalah kemempuan organisasi untuk menggali kebutuhan masyarakat, menyusun agenda dan prioritas pelayanan, dan mengembangkan program pelayanan publik sesuai dengan kebutuhan dan aspirasi masyarakat. Menurut Dwiyanto (2017 :5I) Responsivitas yang rendah ditunjukkan dengan ketidakselaresan antara pelayanan dengan kebutuhan masyarakat. Hal tersebut jelas menunjukkan kegagalan organisasi dalam mewujudkan misi dan tujuan organisasi publik. Organisasi yang memiliki responsivitas rendah dengan sendirinya memiliki kinerja yang jelek pula.

Dwiyanto dan Baveola Kusumasari mengemukakan tentang pentingnya responsivitas dalam hubungannya dengan penilian kinerja yaitu: "Dalam kaitannya dengan penilaian kinerja pelayanan publik, responsivitas sangat diperlukan dalam pelayanan publik karena hal tersebut merupakan bentuk kemampuan organisasi untuk mengenali kebutuhan masyarakat, menyusun agenda, memperioritaskan pelayanan dan mengembangkan program-program pelayanan publik sesuai dengan kebutuhan dan aspirasi masyarakat.

4. Responsibilitas

Responsibilitas menjelaskan apakah pelaksanaan kegiatan organisasi publik itu dilakukan sesuai dengan prinsip - prinsip administrasi yang 
benar atau sesuai dengan kebijakan organisasi, baik yang eksplisit maupun implisit. Oleh sebab itu, responsibilitas bisa saja pada suatu ketika berbenturan dengan responsivitas.

5. Akuntabilitas

Akuntabilitas publik menunjuk pada seberapa besar kebijakan dan kegiatan organisasi publik tunduk pada para pejabat politik yang dipilih oleh rakyat. Asumsinya adalah bahwa para pejabat politik tersebut karena dipilih oleh rakyat, dengan sendirinya akan selalu merepresentasikan kepentingan rakyat. Dalam konteks ini, konsep dasar akuntabilitas publik dapat digunakan untuk melihat seberapa besar kibijakan dan kegiatan organisasi publik itu konsisten dengan kehendak masyarakat banyak.

Kinerja organisasi publik tidak hanya bisa dilihat dari ukuran internal yang dikembangkan oleh organisasi publik atau pemerintah, seperti pencapian target. Kinerja sebaiknya harus dinilai dari ukuran eksternal, seperti nilai - nilai dan norma - norma yang berlaku dalam masyarakat. Suatu kegiatan organisasi publik memiliki akuntabilitas yang tinggi kalau kegiatan itu dianggap benar dan sesuai dengan nilai dan norma yang berkembang dalam masyarakat.

Berdasarkan pengertian kinerja pemerintahan di atas, maka kinerja pemerintahan berarti sekelompok orang dalam organisasi dengan wewenang dan tanggung jawab masing-masing dalam rangka mencapai tujuan atau sekumpulan orang dan individu yaitu pegawai negeri yang berada pada badan atau lembaga pemerintah yang menjalankan fungsi atau tugas pemerintahan.

\section{Efektifitas Organisasi}

Efektivitas organisasi terdiri dari efektivas individu dan kelompok, melalui pengaruh senergitas, organisasi mampu mendaptkan hasil karya yang lebih tinggi tingkatnya dari pada jumlah karya tiap-tiap bagiannya.
Pengertian dasar keefektifan didefenisikan sebagai sejauh mana sebuah organisasi mewujudkan tujuan tujuanya. Dimana efektivitas secara umum menunjukan pada taraf tercapainya hasil, yang sering atau senatiasa sikaitkan dengen pengertian efesian, Efektifitas menekankan pada hasil yang dapat dicapai, sedangkan efesiensi lebih melihat bagaimana cara mencapai hasil yang dicapai itu dengan efesien.

Suatu bentuk organisasi yang dapat dikatakan efektif apabila dapat tercapainya tujuan dari organisasi dengan tepat waktu dan tepat guna dan berdasarkan pendapat Streert (1985:4) dalam Zulkarnain (2012:3334) Pengerttian efektivitas organisasi dapat dijelaskan dengan memahami 3 konsep yang saling berhubungan yaitu :

I) Dalam optimisasi tujuan, keberhasilan yang tercapai oleh suatu organisasi tergantung dari kemampuannya untuk memperoleh dan memanfaatkan sumber dayanya yang langka dan berharga secara sepandai mungkin dalam usahanya mengejar tujuan operasi dan kegiatannya. Dalam hal ini, organisasi harus mengatasi hambatan-hambatan yang dapat menghalangi tercapainya tujuan dan mencari alternatif terbaik guna mencapai tujuan organisasi secara optimal.

2) Dalam perspektif sistem, organisasi terdiri dari berbagai unsur yang saling mendukung dan saling melengkapi. Unsur-unsur tersebut sangat berpengaruh terhadap proses pencapaian tujuan suatu organisasi.

3) Dalam perilaku manusia, tingkah laku individu dan kelompok, menentukan kelancaran tercapainya tujuan suatu organisasi.

Pencapaian efektivitas organisasi meliputi 3 prespektif yang saling berhubungan antara unsur-unsur utama dari system organisasi dan bagaimana unsurunsur tersebut saling mempengaruhi untuk mempermudah atau menghambat pencapaian tujuan organisasi. 
Organisasi dapat dikatakn efektif bila organisasi tersebut dapat sepenuhnya memenuhi sasaran yang telah ditetapkan. Efektivatas umumnya dipandang sebagai tingkat pencapaian tujuan operasional, dengan demikian pada dasarnya efektivitas adalah tingkat pencapaian tujuan atau sasaran organisasi yang sesuai ditetapkan.

\section{METODE PENELITIAN}

Penelitian ini menggunakan metode kuantitatif dengan teknik pengumpulan data menggunakan observasi, wawancara, dukomentasi dan kuisioner. Lokasi pada Kantor Kecamatan Dusun Selatan Kabupaten Barito Selatan, yang beralamat jalan Tugu Buntok Kota Dusun Selatan Kabupaten Barito Selatan, Kal-Teng.

\section{Metode Analisis Data}

\section{Analisis Regresi Sederhana}

Sugiyono (2008:216) menyatakan analisis regresi linier sederhanahubungan fungsional antara satu variabel independen ( $\mathrm{X}$, Kinerja Pegawai) dengan satu variabel dependen (Y, Efektivitas Organisasi. Untuk mengetahui besarnya pengaruh kinerja pegawai terhadap efektivitas organisasi, maka sesuai dengan kebutuhan peneliti, formulasi yang digunakan yaitu :

$$
\begin{aligned}
& \mathrm{Y}=\mathrm{a}+\mathrm{bX} \quad a=\frac{\sum y}{n}-\frac{b\left(\sum x\right)}{n} \\
& Y=\quad \text { Efektivitas Organisasi } \\
& X=\quad \text { Kinerja } \\
& \mathrm{a}=\quad \text { Konstanta } \\
& \mathrm{b}=\quad \text { Koefisien Regresi } \\
& \mathrm{n}=\quad \text { Jumlah responden }
\end{aligned}
$$

\section{Uji Koefesien Regresi Secara Parsial (uji t)}

Menurut Syofian Siregar (20I5) uji t adalah uji statistik bagi koefisien regresi dengan hanya satu koefisien regresi yang mempengaruhi variabel bebas. $U_{j i}$ t digunakan untuk mengetahui ada tidaknya hubungan atau pengaruh yang signifikan antara variabel bebas $(X)$ yaitu Kinerja Pegawai (Y) Efektvitas Organisasi yang diteliti. Signifikan dalam hal ini artinya pengaruh yang terjadi dapat berlaku untuk populasi.
I. Jika $t_{\text {hitung }}<t_{\text {tabel }}$ maka Ho diterima, artinya Kinerja Pegawai tidak berpengaruh terhadap Efektivitas Organisasi pada Kantor Kecamatan Dusun Selatan Kabupaten Barito Seltana Tahun 2020.

2. Jika $t_{\text {hitung }}>t_{\text {tabel }}$ maka Ho ditolak, artinya Kinerja Pegawai berpengaruh terhadap Efektivitas Organisasi pada Kantor Kecamatan Dusun Selatan Kabupaten Barito Selatan Tahun 2020

\section{Uji Validitas}

Menurut Sugiyono (2017:121) Uji Validitas Data adalah :Instrumen yang valid berarti alat ukur yang digunakan untuk mendapatkan data (mengukur) itu valid. Valid berarti instrumen tersebut dapat digunakan untuk mengukur apa yang seharusnya diukur. Hasil penelitian yang valid bila terdapat kesamaan antara data yang terkumpul dengan data yang sesungguhnya terjadi pada objek yang diteliti.

\section{Pengujian Reliabilitas}

Menurut Ghozali (2006) uji Reliabilitas adalah alat untuk mengukur suatu kuesioner yang merupakan indicator dari variabel. Suatu kuesioner dikatakan handal jika jawaban seseorang terhadap pertanyaan adalah konstan atau stabil dari waktu ke waktu. Uji reliabilitas digunakan untuk menguji sejauh mana hasil suatu pengukuran dapat dipercaya.

Realibilitas pengukuran ditentukan dengan menghitung koefisien Cronbach dari masing-masing instrument dalam satu variabel. Instrument dapat dikatakan handal (reliable) bila memiliki koefisien Cronbach alpha yang semakin mendekati I atau semakin tinggi koefisien internal reliabilitasnya (Sekaran, 2006). Sementara menurut Ghozali (2005), bahwa instrument dapat dikatakan handal (reliabel) bila memiliki koefisien Cronbach alpha $\geq 0,6$. 


\section{PEMBAHASAN}

\section{Rekapitulasi Jawaban kuisioner}

Rekapitulasi Hasil jawaban kuisioner yang di dapat dari

34 responden Pegawai Dinas Kependudukan dan Pencatatan Buntok yang terdiri dari variabel Kinerja Pegawai (X) dan Efektivitas Organisasi (Y) Di masukkan dalam tabel rekapitulasi jawaban.

Rekapitulasi Hasil Uji Validitas dan Reabilitas Untuk Untuk Mengukur Pengaruh Kinerja Pegawai Terhadap Efektivitas Organisasi pada Kantor Kecamatan Dusun Selatan Kabupaten barito selatan

\section{Tabel 4.2 Hasil Uji Validitas Variabel (X)}

\begin{tabular}{|c|c|c|c|}
\hline $\begin{array}{c}\text { Item } \\
\text { Pertanyaan }\end{array}$ & $\begin{array}{c}\text { Skor } \\
\text { Total }\end{array}$ & Validitas & Keterangan \\
\hline Item I / PI & 0,496 & 0,36 I & Valid \\
\hline Item 2 / P2 & 0,543 & 0,36 I & Valid \\
\hline Item 3 / P3 & 0,43 I & 0,36 I & Valid \\
\hline Item 4 / P4 & 0,772 & 0,36 I & Valid \\
\hline Item 5 / P5 & 0,682 & 0,36 I & Valid \\
\hline Item 6 / P6 & 0,760 & 0,36 I & Valid \\
\hline Item 7 / P7 & 0,503 & 0,36 I & Valid \\
\hline Item 8 / P8 & 0,705 & 0,36 I & Valid \\
\hline Item 9 / P9 & 0,480 & 0,36 I & Valid \\
\hline Item I0 / PI0 & 0,573 & 0,36 I & Valid \\
\hline
\end{tabular}

\section{Tabel 4.3 Hasil Uji Validitas Variabel (Y)}

\begin{tabular}{|c|c|c|c|}
\hline $\begin{array}{c}\text { Item } \\
\text { Pertanyaan }\end{array}$ & $\begin{array}{c}\text { Skor } \\
\text { Total }\end{array}$ & Validitas & Keterangan \\
\hline Item I / PI & 0,686 & 0,36 I & Valid \\
\hline Item 2 / P2 & 0,680 & 0,36 I & Valid \\
\hline Item 3 / P3 & 0,496 & 0,36 I & Valid \\
\hline Item 4 / P4 & 0,684 & 0,36 I & Valid \\
\hline Item 5 / P5 & 0,759 & 0,36 I & Valid \\
\hline Item 6 / P6 & 0,4 I7 & 0,36 I & Valid \\
\hline Item 7 / P7 & 0,832 & 0,36 I & Valid \\
\hline Item 8 / P8 & 0,769 & 0,36 I & Valid \\
\hline Item 9 / P9 & 0,80 I & 0,36 I & Valid \\
\hline Item I0 / PI0 & 0,4 I8 & 0,36 I & Valid \\
\hline
\end{tabular}

\section{Tabel 4.4 Hasil Uji Reabilitas Variabel (X)}

\begin{tabular}{|c|c|c|}
\hline $\begin{array}{c}\text { Item } \\
\text { Pertanyaan }\end{array}$ & $\begin{array}{c}\text { Cronbach's } \\
\text { Alpha If Item } \\
\text { Deleted }\end{array}$ & Keterangan \\
\hline Item I / PI & 0,793 & Reliabel \\
\hline Item 2 / P2 & 0,790 & Reliabel \\
\hline Item 3 / P3 & 0,803 & Reliabel \\
\hline Item 4 / P4 & 0,756 & Reliabel \\
\hline Item 5 / P5 & 0,770 & Reliabel \\
\hline Item 6 / P6 & 0,758 & Reliabel \\
\hline
\end{tabular}

\begin{tabular}{|c|c|c|}
\hline Item 7 / P7 & 0,795 & Reliabel \\
\hline Item 8 / P8 & 0,767 & Reliabel \\
\hline Item 9 / P9 & 0,797 & Reliabel \\
\hline Item I0 / PI0 & 0,786 & Reliabel \\
\hline
\end{tabular}

\section{Tabel 4.4 Hasil Uji Reabilitas Variabel (Y)}

\begin{tabular}{|c|c|c|}
\hline $\begin{array}{c}\text { Item } \\
\text { Pertanyaan }\end{array}$ & $\begin{array}{c}\text { Cronbach's } \\
\text { Alpha If Item } \\
\text { Deleted }\end{array}$ & Keterangan \\
\hline Item I / PI & 0,838 & Reliabel \\
\hline Item 2 / P2 & 0,839 & Reliabel \\
\hline Item 3 / P3 & 0,858 & Reliabel \\
\hline Item 4 / P4 & 0,838 & Reliabel \\
\hline Item 5 / P5 & 0,830 & Reliabel \\
\hline Item 6 / P6 & 0,859 & Reliabel \\
\hline Item 7 / P7 & 0,82 I & Reliabel \\
\hline Item 8 / P8 & 0,829 & Reliabel \\
\hline Item 9 / P9 & 0,825 & Reliabel \\
\hline Item I0 / PI0 & 0,863 & Reliabel \\
\hline
\end{tabular}

Untuk Mengukur Pengaruh Pengaruh Kinerja Pegawai Terhadap Efektivitas Organisasi Pada Kantor Kecamatan Dusun Selatan Kabupaten Barito Selatan menggunakan Regresi linier sederhana

\section{Hasil Perhitungan SPSS versi 25}

\section{Uji Regresi Linear Sederhana}

Berdasarkan hasil analisis yang telah dilakukan, maka persamaan regresi yang terbentuk adalah sebagai berikut:

$$
Y=7,098+0,848 X
$$

Dari hasil persamaan regresi linear sederhana, dapat diketahui bahwa :

persamaan ini adalah nilai konstanta (a) sebesar 7,098 artinya jika pengaruh kinerja pegawai $(X)$ nilai skornya adalah 0 , maka efektivitas organisasi $(Y)$ nilai skornya sebesar 7,098. Kemudian koefisien regresi variabel kinerja $(X)$ sebesar 0,848 artinya jika nilai skor kinerja mengalami kenaikan sebanyak I kali, maka efektivitas (Y) akan mengalami peningkatan sebesar 0,848 , serta koefisien bernilai positif artinya terjadi hubungan positif antara Kinerja Pegawai (X) dengan Efektivitas Organisasi (Y) 


\section{Untuk Mengukur Pengaruh Kinerja Pegawai Terhadap Efektivitas Organisasi Pada Kantor Kecamatan Dusun Selatan Kabupaten Barito} Selatan, maka digunakan uji secara parsial (uji t)

Berdasarkan ouput diperoleh $t_{\text {hitung }}$ yang di olah menggunakan SPSS versi 25 sebesar 6,538 (bisa dilihat di table 35 ). Adapun hasil angka perhitungan $t_{\text {hitung }}$ manual adalah 6,538 dengan angka murni $t_{\text {hitung }}=$ 6,5382236863562 maka di ambil 3 angka di balakang koma adalah 6,538 maka hasil hitungan manual sama dengan hitungan SPSS versi $25=6,538$

Tingkat signifikan 0,05 atau 5\% adalah ukuran standar yang digunakan dalam suatu penelitian. Jadi dalam penentuan $t_{\text {tabel }}$ dengan uji 2 sisi signifikan 0,025 hasil diperoleh untuk $t_{\text {tabel }}$ sebesar 2,042.

Dari pengujian di atas bahwa $t_{\text {hitung }}>t_{\text {tabel }}(6,538$ $>2,042$ ) ma Ho ditolak dan Ha diterima, artinya bahwa ada pengaruh secara signifikan antara Kinerja Pegawai terhadap Efektivitas Organisasi pada kantor Kecamatan Dusn selatan tahun 2020.

\section{Uji Hipotesis}

Berdasarkan Output di peroleh hasil $t_{\text {hitung }}$ sebesar 6,538 dengan tingkat signifikan 0,05 atau 5\% yang sering digunakan sebagai ukuran standar dalam penelitian. Kemudian dalam menentukan $\mathrm{t}_{\text {tabel }}$ dicari $\mathrm{a}=$ $5 \%: 2=2,5 \%$ (uji 2 sisi) dengan derajat kebebasan (df) $\mathrm{n}-\mathrm{k}-\mathrm{I}$ atau $30-2-\mathrm{I}=27$ (dimana $\mathrm{n}$ adalah jumlah sampel / responden dan $\mathrm{k}$ adalah jumlah dari variabel). Dengan uji 2 sisi signifikan 0,025 di peroleh hasil untuk $t_{\text {tabel }}$ adalah 2,042.

Dari hasil pengujian di atas bahwa $t_{\text {hitung }}>t_{\text {tabel }}$ (6,538 > 2,042) maka Ho ditolak dan Ha diterima, artinya bahwa ada pengaruh secara signifikan antara Kinerja Pegawai terhadapa Efektivitas Organisasi pada Kantor Kecamatan Dusun Selatan.

Artinya dalam hal ini, dugaan pada Hipotesis yaitu terdapat pengaruh antara Kinerja Pegawai terhadap Efektivitas Organisasi pada Kantor Kecamatan
Dusun Selatan Kabupaten Barito Sealatan tahun 2020 menyatakan dugaan Hipotesis tersebut adalah benar.

Kemudian semua indikator variabel Kinerja $(X)$ memberikan pengaruh jika dilihat pada indikator Produktivitas, Kualitas Pelayanan, Responsivitas, Responsibilitas, Akuntabilitas, terhadap variabel Efektivitas Organisasi (Y) pada indikator Pencapaian tujuan, Integrasi, Adaptasi.

\section{KESIMPULAN}

I. Berdasarkan hasil temuan, saat peneliti membagikan kuesioner, peneliti menyebar 30 kuesioner ke 30 orang pegawai di Kantor Kecamatan Dusun Selatan dengan menggunakan sistem manual yaitu membagian lembaran pernnyataan yang akan di isi oleh pegwai di Kantor Kecamatan Dusun Selatan yang akan jadi bahan untuk peniliti, dimulai pada hari rabu, 3 Maret 2020 sampai dengan 9 Maret 2020. jumlah responden yang berpartisipasi dalam pengisian kuesioner hanya 30 orang responden saja, karena peniliti hannya meniliti Pegawai Negeri Sipi (PNS) sebagai sampel, karena untuk 30 orang Pegawai Negeri Sipil (PNS) responden sudah cukup untuk dilakukan uji aplikasi SPSS 25, karena untuk menggunakan uji aplikasi SPSS 25 peneliti minimal mencari sampel 30 .

2. Dalam mengukur tingkat kevalidan data, bahwa semua pernyataan kuisioner dari poin I sampai 10 sudah sesuai dengan varibel Kinerja Pegawai (X). Dalam variabel Kinerja Pegawai $(X)$ tingkat kevalidan pernyataan paling tinggi yaitu ada pada indikator Kualitas Layanan dengan item pernyataan "Pegawai mampu memenuhi kebutuhan masyarakat dalam menyediakan layanan” dengan total skor 0,772. Kemudian pada indikator variabel Efektivitas Organisasi (Y), semua item pernyataan kuisioner poin I sampai 10 sudah sesuai dengan variabel Efektifitas Organisasi (Y). Dalam variabel Efektivitas Organisasi ( $Y$ ) tingkat kevalidan pernyataan paling tinggi yaitu ada pada indikator Adaptasi dengan item 
pernyataan "Pegawai dapat menyesuaikan diri dengan program-program yang baru" dengan total skor 0,832 .

3. Dari hasil uji reliabilitas, bahwa semua pernyataan varibel Kinerja Pegawai $(X)$ kuisoner I sampai 10 sudah reliabel, di dapat nilai Cronbach's Alpha sebesar 0,800. Maka nilai cronsbach's alpha 0,800 > 0,60 sehingga dapat dikatakan bahwa kuesioner tersebut reliabel atau konsisten. Dari hasil uji reliabilitas pada variabel Efektivitas Organisasi (Y), bahwa semua pernyataan variabel Efektivita Organisasi (Y) kuisoner I sampai 10 sudah reliabel, di dapat nilai Cronbach's Alpha sebesar 0,855. Maka nilai cronsbach's alpha $0,855>0,60$ sehingga dapat dikatakan bahwa kuesioner tersebut reliabel atau konsisten.

4. Hasil yang diperoleh dalam perhitungan regresi linier sederhana adalah $Y=7,098+0,848 X$ dimana nilai (a) sebesar 7,098 dan nilai koefisien (b) adalah 0,848. Hasil dari penelitian ini dapat disimpulkan bahwa Kinerja Pegawai dapat meningkatkan Efektivitas. Sehingga Kinerja dapat memberikan kontribusi yang bagus dan positif terhadap Efektivitas Organisasi.

Kemudian diperoleh hasi $t_{\text {hitung }}$ dari pengujian di atas bahwa $t_{\text {hitung }}>t_{\text {tabel }}(6.538>2,035)$ maka Ho ditolak dan $\mathrm{Ha}$ diterima, artinya bahwa ada pengaruh secara signifikan antara Kinerja Pegawai terhadap Efektivitas Organisasi pada Kantor Kecamatan Dusun Selatan Tahun 2020. Artinya dalam hal ini, dugaan pada Hipotesis yaitu Terdapat Pengaruh antara Kinerja Peagawai Terhadap Efektivitas Organisasi pada Kantor Kecamatan Dusun Selatan Kabupaten Barito Selatan Tahnu 2020 menyatakan dugaan Hipotesis tersebut adalah benar.

\section{REFERENSI}

Dwiyanto, Agus. (2017). Reformasi Birokrasi Publik. Gadjah Mada University Press

Ghozali, Imam. 2006. Aplikasi Analisis Multivariate Dengan Program SPSS. Cetakan Keempat. Semarang: Badan Penerbit Universitas Diponegoro

Hariandja, Marihot Tua Effendi. (2002). Manajemen Sumber Daya Manusia. Jakarta: Grasindo

Mahmudi (2005). Manajemen Kinerja Sektor Publik. Yogyakarta: UPP AMP YKPN.

Mangkunegara, Anwar Prabu. (2005). Evaluasi Kinerja Sumber Daya Manusia. Bandung : Refika Aditama.

Purwanto Agus, dan Dyah Ratih Sulistyastuti, (2007). Metode Penelitian Kuantitatif, Untuk Administrasi Publik, dan Masalah-masalah Sosial.Yogyakarta: Gaya Media.

Richard M. Steers. (1998). Efektivitas organisasi penerbit Erlangga, Bandung.

Ridwan. (2003). Skala Pengukuran Variabel-variabel Penelitian, Penerbit Alfabeta, Bandung.

Ruky S Achmad. (200I).Sistem Manajemen Kinerja. PT Gramedia, Jakarta.

Rivai. (2009). Manajemen Sumber Daya Manusia, Jakarta cetakan kesembilan.

Rizki, Ahmad S. (200I). Manajemen Penggajian dan Pengupahan Karyawan Perusahaan. Gramedia Utama : Jakarta

Sugiyono. (2006). Metode Penelitian Kuantitatif, Kualitatif dan R \& D. Bandung:Alfabeta. (20II). Metode Penelitian Kuantitatif, Kualitatif dan R \& D. Bandung:Alfabeta.

(20I3). Metode Penelitian Kuantitatif, Kualitatif dan R \& D. Bandung:Alfabeta. 2005. Aplikasi Analisis Multivariate dengan SPSS. Semarang: Badan Penerbit UNDIP.

V Wiratna Sujarweni. (2015). Metodologi Penelitian Bisnis dan Ekonomi. Yogyakarta: Pustaka Baru Press.

Tangkilisan, Hessel Nogi. (2005). Manajemen Publik. Gramedia Widia. Jakarta.

Wibowo. (2007), Manajemen Kinerja. Jakarta: PT. Raja Grafindo Parsada.

Wirawan. (2009). Evaluasi Kinerja Sumber Daya Manusia Teori Aplikasi dan Penelitian. Jakarta. Penerbit: Salemba Empat.

Zulkarnain.2012. Pengaruh Kinerja Pegawai Terhadap Efektivitas Organisasi di Kantor Kecamatan Kelapa Dua Kabupaten Tanggerang 